\title{
Maedi-visna
}

\author{
PÁLL A. PÁLSSON
}

From the Institute for Experimental Pathology, University of Iceland, Keldur, Reykjavik

Rise in temperature is not observed in visna or maedi. The animals seem to be remarkably alert and the appetite remains unaffected throughout.

The period between inoculation of infective visna material and the development of clinical signs varies from animal to animal even with a standard dose. Usually this period is very long and several months to several years may elapse before clinical signs can be detected.

\section{Transmission Experiments}

In transmission experiments a prolonged leucocytosis in the blood is often observed as in maedi and there is an increased number of mononuclear cells (50$200 \mathrm{~mm}^{3}$ ) in the cerebrospinal fluid which is often found a few weeks after inoculation but sometimes not for several months. In all natural cases of visna examined, pleocytosis of the cerebrospinalfluid has been found. In some cases pleocytosis remains throughout the course of the disease, in others there is a great fluctuation in the number of mononuclear cells observed. An increase in the content of gammaglobulins of the CSF is often found from the onset of pleocytosis, but does not always run parallel with it (Sigurdsson et al, 1960).

After intracerebral or intrapulmonary injection of recently isolated maedi virus (M88 and M2219) typical visna disease has been produced. On the other hand, by inoculating visna virus (K796) intracerebrally into sheep, lesions typical of maedi have been produced several times together with those of visna (Gudnadóttir, and Pálsson, 1967).

In sheep affected by maedi, in the field virus can be demonstrated in the choroid plexus in approximately $25 \%$ of the cases although the sheep showed no sign of a nervous disorder (Gudnadóttir, Gíslason, and Pálsson, 1968).

We now consider visna and maedi to be two different manifestations of the same viral infection.

Attempts to infect laboratory animals with visna and maedi virus have been unsuccessful and attempts to hyperimmunize these animals have also failed.

\section{Pathology}

Postmortem changes in maedi are confined to the lungs and associated lymph nodes. In advanced cases, the weight of the lung is increased to two to four times that of a normal lung; the lungs are voluminous and collapse only slightly when the thoracic cavity is opened. Increase in the size of the lung, however, is not so noticeable as is the increase in weight. The shape of the enlarged lung remains normal and the affected tissue is of firm often somewhat fleshy consistency. The normal pinkish-red colour of a healthy sheep lung is replaced by a characteristic gray-brownish colour. The most advanced lesions are usually found in the diaphragmatic lobes, but are less pronounced in the cardiac and apical lobes. There is never a distinct borderline between affected and healthy lung tissue. The lymph nodes associated with the lung are always enlarged and soft and their cut surface is homogenous and whitish (Sigurdsson, Grímsson, and Pálsson, 1952).

The main histopathological change in maedi is a chronic interstitial inflammation with diffuse thickening of the interalveolar septa, sometimes leading to the total obliteration of the alveoli. The thickening of the interalveolar septa is mainly due to infiltration with large mononuclear cells, and to a lesser extent to lymphocytes. Hyperplasia of smooth muscles in the interalveolar walls is often observed and peribronchial and perivascular proliferation of lymphoid tissue is always marked. Hyperplasia of the epithelium in small bronchioles is often found, sometimes accompanied by disorganization and epithelialization of adjacent alveoli (Georgsson and Pálsson, 1971).

In sheep dying from uncomplicated visna no specific macroscopic postmortem changes are seen. Atrophy of the muscles of the hind limbs is often found when the course of the disease has been very protracted. In a few cases congestion of the meninges is observed and small grey-yellow plaques may be found in sections of the white matter.

The primary microscopical lesions in the central nervous system is the appearance of meningeal or subependymal infiltrations and proliferation of cells of the reticuloendothelial system. In advanced cases extensive lesions can be found throughout the white matter at all levels of the brain and the brainstem, pons, medulla, and the spinal cord. The lesions apparently begin as tiny foci of microglial infiltra- 
tion which, on becoming confluent, give rise to larger lesions or even large, massively infiltrated areas, which show a tendency to necrose and form cavities. Myelin degeneration is secondary and often rather mild and the axis cylinders are relatively well preserved. Extra- and intracellular sudanophil products are infrequent and fibrillar glial organization is always mild. In the involved areas, the lesions are accompanied by extensive perivascular cuffs of lymphocytes, plasma cells, and histiocytes. The peripheral nerves show diffuse lymphocytic infiltration, whereas the changes in the myelin sheets are comparatively mild.

There is not necessarily any relationship between the duration of the disease and the severity of the lesions. Whether the onset of visna lesions can be correlated with certain immunological conditions of the host has not been worked out (Sigurdsson, Pálsson, and van Bogaert, 1962).

In flocks naturally affected with maedi, complement-fixing antibodies and neutralizing antibodies against maedi and visna virus can be demonstrated and are most frequent in the older sheep of the flocks. These antibodies occur long before any clinical signs of a disease are detectable (Gudnadóttir and Kristinsdóttir, 1967). The highest incidence of maedi is found in those flocks which show the highest titre of neutralizing antibodies (Thormar, Gílason, and Helgadottír, 1966).

In experimental cases of maedi and visna, it has been shown that neutralizing antibodies are usually detectable in moderate titre three to six months after infection. Complement-fixing antibodies are, however, detectable after a few weeks and are found in some cases where no neutralizing antibodies are detectable. These antibodies seem to persist in high titre for many years, and when killed sheep with high levels of antibody often show pronounced pathological lesions (Gudnadóttir and Kristinsdóttir. 1967).

Maedi virus propagates in tissue cultures from sheep and virus multiplication is accompanied by a cytopathic effect characterized by the formation of multinucleated syncytia. In most instances the infection leads to a complete disintegration of the cell culture (Sigurdardóttir and Thormar, 1964). Attempts to transmit maedi by injecting culture passage of the virus intrapulmonarily into sheep were successful.

The transmitted disease progresses slowly and two to four years elapse before macroscopic lesions can be observed in the lungs, but during this period lesions are detectable microscopically and a gradual increase in the total weight of the lungs takes place as the pathological lesions progress. During this preclinical period, maedivirus can often be recovered from blood (leucocytes), cerebrospinal fluid, and various organs of the animal (Gudnadóttir and Pálsson, 1967).

\section{Virology}

Visna was also found to be a transmissible disease, often with a latent preclinical period of one to two years following intracerebral inoculation with brain material of affected sheep into healthy ones (Sigurdsson, Pálsson, and Grímsson, 1957). Visna virus was first propagated in primary cultures of sheep choroid plexus cells, and in most studies of this agent such cell cultures have been used. Later the virus was propagated in cultures of lung, spleen, peritoneal, heart, cerebellar, testes, adrenal gland, and kidney cells of sheep. Infected cultures develop characteristic cytopathic changes resembling the changes caused by maedi virus (Sigurdsson, Thormar, and Pálsson, 1960).

Newly formed virus is first detected after a latent period of 16 to 20 hours and during the following 16 hours titres increase rapidly and virus continues to be produced until the cell sheet shows extensive degeneration after 96 to 120 hours (Thormar, 1963; Harter and Choppin, 1967).

After several passages, tissue culture virus was capable of producing typical visna lesions and a clinical disease similar to natural visna on intracerebral infection. Visna has also been induced in experimental sheep by intrapulmonary inoculation (Gudnadóttir and Pálsson, 1965b). Visna virus has too been shown to multiply in a continuous line of embryonic bovine trachea cells (Harter, Hsu, and Rose, 1968).

The chemical and physical properties of visna and maedi viruses were found to be almost identical (Thormar, 1965a and b). Both viruses are sensitive to chloroform, ether, methaperiodate, and trypsin and are inactivated at the same rate by $0.04 \%$ formaldehyde, ultraviolet light, and heat $\left(56^{\circ} \mathrm{C}\right.$ for $\mathrm{min}$ ). At $p \mathrm{H} \mathrm{4.2}$ maedi virus was, however, inactivated three times more rapidly than visna virus (Thormar, 1966).

Electron microscopic studies of visna virus multiplication in sheep choroid plexus cells showed budding of the external cell membrane and accumulation of extracellular, spherical, virus-like particles, averaging $85 \mathrm{~m}_{\mu}$ in diameter and having a dense core (Thormar, 1961, 1965a and b; Coward, Harter, and Morgan, 1970). Negative staining showed a myxovirus-like structure (Thormar and Cruickshank, 1965; Pautrat, Tamalet, ChippauxHyppolite, and Brahie, 1971).

Fluorescent antibody techniques have shown that the viral antigen is produced in the cytoplasm and 
accumulates later at the cell surface (Harter, Hsu, and Rose, 1967; Thormar, 1969).

In recent studies it has been established that visna virus contains RNA with a sedimentation coefficient of $64 \mathrm{~S}$ and that the visna virion contains a RNAdependent DNA polymerase (Harter, Rosenkranz, and Rose, 1969; Lin and Thormar, 1970a and b; Schlom, Harter, Burny, and Spiegelman, 1971; Stone, Scolnick, Takemote, and Aaronson, 1971). This enzyme had previously only been found in RNA tumour viruses. Visna and maedi viruses have, however, never been found to be tumorigenic in sheep.

\section{Clinical Course}

\section{MAEDI}

In infected flocks, maedi is found only in adult sheep more than 3-4 years old. The course of the disease usually lasts for four to eight months, but in some cases much longer, even for years. Within a flock the spread is at first very slow and usually no clinical cases are observed for the first five to six years after the infection has been introduced. During the following three to four years the mortality rate increases rapidly until an annual mortality rate of 20 to $30 \%$ is reached.

The onset of maedi is very insidious. Leucocytosis is often observed for more than a year before clinical signs are observed. The main clinical features are progressive loss of condition and rapid and laboured respiration: the animals finally become dyspnoeic and respiration, which is increasingly helped by the accessory respiratory muscles, is often accompanied by rhythmic jerks of the head and flanks. Affected sheep frequently succumb to a secondary pneumonia.

\section{VISNA}

In the field visna was never observed in animals under 2 years of age. Affected sheep lag behind when the flock is driven and stumbling and weakness of the hind limbs is observed as one of the first signs of the disease. At the same time there is some loss in condition. Later the power to extend the fetlocks is impaired and often the sheep are seen resting the distal end of the metatarsus on the ground. Gradually the paresis of the limbs progresses, resulting in difficulty in walking and increased fatigue on exertion. Sometimes trembling of the lips and eyelids is seen, and the head is often turned a little to one side.

The course both of natural and transmitted cases of visna is very protracted and usually several months, often several years, elapse before the stage of paraplegia or total paralysis is reached. Some- times the disease progresses in waves with slight remissions. Physical strain or repeated general anaesthesia seem to accelerate the disease.

\section{Maedi and Visna in Iceland}

Maedi which means dyspnoea, is a slow progressive viral pneumonia of sheep and when it was first recognized in Iceland in 1939 by Gíslason it was already prevalent on a great number of farms in two different areas of the country. Apparently the disease had spread unnoticed in these areas following the importation six years earlier of a few apparently healthy Karakul sheep from Halle, Germany, to certain farms in these areas (Gíslason, 1947). The German flock of Karakul sheep has apparently been self-contained for at least the last 30 years and neither maedi nor visna has ever been observed in it and it is still (1971) maintained in Leipzig (O. C. Straub, personal communication, 1971).

In individual flocks in Iceland the annual mortality rate from maedi was often $20-30 \%$ and this heavy mortality continued year after year, with little evidence that the epidemic was subsiding or resistant sheep strains were emerging. The government therefore decided to make an attempt to eradicate the disease by slaughtering all sheep in the affected areas, and replacing them with young stock from uninfected parts of the country. This eradication scheme was carried out between 1944 and 1952 and in most areas it was successful. In certain districts, however, mainly in the western part of the country, maedi reappeared several times between 1954 and 1965 in some flocks of the new stock. Only a few farms were affected at a time and the disease was again eradicated by destroying all affected and in-contact flocks. The last appearance of maedi, which was restricted to one flock only, occurred in 1965 and since then Iceland has been free of this disease.

It has been estimated that more than 150000 sheep have succumbed to maedi, and more than 600000 sheep had to be killed in order to eradicate the disease.

\section{EPIDEMIOLOGY}

Visna, which means wasting, is a name which has been given to a slow viral disease causing a fatal meningitis and encephalomyelitis of sheep in Iceland. This disease was first observed in flocks in the south-western part of the country in 1940 (Gíslason, personal communication). Cases of visna were only found in the field in flocks where maedi had been prevalent for several years and a number of them were brought to our laboratory for study. All these sheep were also affected with maedi at 
various stages and from the beginning of our studies a relationship between maedi and visna was suspected. It is, however, noteworthy that in the two main epidemics of maedi, which occurred simultaneously in two different parts of the country, maedi was accompanied by visna in only one of them, and in the restricted epidemics of maedi occurring later in the western part of Iceland, visna was never observed. A possible explanation of this might be that the epidemics where visna was never found terminated after a fairly short period of time, so the infection never became as intense and massive as in the big epidemic which lasted for 15 to 18 years before it was brought to an end. On most farms only sporadic cases of visna occurred, on others the losses from visna could reach $10 \%$ annually and in some individual flocks the losses exceeded those caused by maedi (Snorrason, personal communication, 1950).

Since the slaughtering of all sheep in visnaaffected areas in order to eradicate maedi was accomplished in 1952, natural cases of visna have not been observed. The disease has been maintained in the laboratory by sheep-to-sheep passage of brain material or tissue culture virus using fifth and sixth sheep-passage virus from natural cases of visna.

When the heavy losses caused by maedi and visna in Iceland are considered, it should be borne in mind that the Icelandic sheep are a primitive breed which were brought to the country by the settlers more than one thousand years ago. Since then the sheep population, a breeding stock of approximately 800000 sheep, has lived in almost complete isolation, since import of sheep has been very rare indeed and of very small number. Thus it is probable that Icelandic sheep differ considerably genetically from other European breeds.

Epidemiological observations indicated that maedi was a contagious disease with a very long latent or preclinical period of two to three years. During the preclinical period, the disease was apparently very rarely transmitted, except from the mother to offspring. On the pasture communicability of maedi appeared to be low, even in the clinical stage, whereas close contact of sheep while housed during the winter seemed to favour the transmission of the disease (Gíslason, 1947). Maedi was transmitted to experimental sheep by feeding drinking water contaminated with faeces from diseased sheep and by injecting material from typical maedi lungs and mediastinal lymph nodes intravenously, intrapulmonarily, and intranasally into healthy young sheep (Sigurdsson, Pálsson, and Tryggvadóttir, 1953).

Virus strains were first isolated in tissue culture from lungs showing typical maedi lesions by the late Dr Sigurdsson in 1958 (personal communication).
Later maedi virus was isolated from various organs of maedi-infected sheep, most frequently from lungs, mediastinal lymph nodes, and spleen, and from cerebrospinal fluid and blood (leucocytes) but rarely from nasal or throat swabs.

Low titres of neutralizing and complement-fixing antibodies have sometimes been demonstrated in the cerebrospinal fluid of experimentally infected sheep.

There is a close serological relationship between visna and maedi viruses. Maedi antisera neutralize visna virus to the same titre as the homologous maedi virus strains. This was also true for sera from natural cases of maedi, which had never had any contact with visna virus.

Antisera against visna virus also neutralized maedi virus but to a lower titre, depending both on the antiserum and on the maedi strain. Apparently the antigenic structure of maedi virus is broader than that of visna virus, but there seems to be some difference in the antigenic constitution of the various strains (Thormar and Helgadóttir, 1965).

Sheep infected with visna and maedi viruses form antibodies detectable by fluorescein labelling shortly after infection. The presence of fluorescent antibody was found to correlate with complement-fixing rather than neutralizing antibodies (Thormar, 1969).

In visna-infected sheep, no virus-neutralizing activity has been found in the immune globulin classes, slow IgG, fast IgG, and IgM. This adds support to the notion that the immune response in visna is deficient compared with that of other viral infections (Pétursson, 1970). It is also noteworthy that in long-term experiments virus can be isolated repeatedly from blood of sheep in spite of a good antibody response in many cases (Gudnadóttir and Pálsson, 1965a).

\section{Viruses Similar to Maedi and Visna}

Slow progressive pneumonias of sheep that are pathologically very similar to maedi have been described from various parts of the world. After the isolation of maedi and visna viruses some attempts were made to study the relationship of these various diseases. These studies showed that maedi and visna were serologically related to zwoegerziekte of sheep in Holland and to progressive pneumonia of sheep in Montana (Thormar, 1966). Viruses closely related to maedi and visna have been isolated from sheep with zwoegerziekte, and transmission experiments to sheep have shown a very close relationship to maedi (de Boer, 1970a and b). In flocks affected with zwoegerziekte, visna-like meningoencephalitis has occasionally been reported (Ressang, Stam, and de Boer, 1966). Recently viruses having properties similar to maedi and visna have also been isolated 
from cases of progressive pneumonia in Montana (Kennedy, Eklund, Lopez, and Hadlow, 1968; Lopes, Eklund, and Hadlow, 1970; Takemoto, Mattern, Stone, Coe, and Lavell, 1971) and from sheep of the Texel breed in West Germany and Denmark (Straub, 1970; Hoff-Jørgensen, 1971).

Maedi-like pneumonia in sheep has also been reported in India (Rajya and Singh, 1964), in France (la 'bouhite') (Lucam, 1942), in South Africa (Graaf-Reinet disease) (de Kock, 1929), and in Kenya (Wandera, 1970) where a serological relationship to maedi and visna was found. Visna-like disease primarily affecting the central nervous system is apparently unknown or very rare indeed in these countries and it has only been reported from Holland.

Prompted mainly by information obtained while studying visna and maedi in sheep in lceland, Sigurdsson coined the term 'slow viral infection' many years ago. He characterized such infections by the following criteria: (1) A very long initial period of latency up to several years during which time there is an active viral proliferation and spread throughout the host in the absence of clinical signs. (2) A fairly regular protracted course after clinical signs of illness have appeared, usually ending in serious disease or death of the host. (3) Limitation of the natural infection to a single host species and localization of anatomical lesions to a single organ or tissue system (Sigurdsson, 1954). This last criterion has been shown to be invalid as knowledge of these diseases has increased as has been forecast by Sigurdsson. In 'slow viral infections' the anatomical lesions and the appearance and progression of the clinical symptoms follow a set pattern, and once clinical signs of disease are recognized they progress continuously to a fatal end, and thus they differ from a chronic disease, where the course is often irregular and unpredictable.

This concept that a virus can cause relentlessly progressive fatal pathological lesions over a long time, sometimes lasting for the better part of the total life span of the host, has doubtless been useful in the study and concept of the pathogenesis of certain subacute diseases of animals and man. However, even in diseases like maedi and visna, where the infective agent has been demonstrated and is comparatively well known, our understanding of the pathogenesis is still limited and fragmentary.

Maedi and visna are systemic infections not confined to one organ, but infecting many organs including those of the reticuloendothelial system such as spleen and lymph glands, although the lungs and the central nervous system are the target organs where the pathological lesions are found.

Many years ago Sigurdsson posed the question,
Why does it take the infective agent so long to produce enough lesions to cause a clinical disease? Why is the infective agent not eliminated by the defence mechanism of the host? We do not yet have answers to these important questions. In experimentally transmitted cases of visna, neutralizing antibodies are formed a comparatively long time (months or years) after infection, and clinical cases have developed neutralizing antibodies by the time the first signs of disease occur. As a plausible explanation of the first question it has been proposed that an antigen-antibody reaction takes place on the surface of infected cells and neutralizing antibodies cause cell destruction and secondary demyelination (Gudnadóttir and Pálsson, 1965). It has also been shown that visna virus particles possess the ability to alter cell membranes leading to cell fusion and eventual cell disintegration, and that this occurs even in cell cultures where virus does not multiply. If something comparable takes place in the host an infection of the cell might not even be necessary to produce an injury of the cell membrane and later destruction (Harter and Choppin, 1967; Bunge and Harter, 1969).

As a possible explanation of the apparent inefficiency of the protection of the persistent antibodies found in visna and maedi the following has been proposed. The virus budding from the surface of infected cells possibly acquires an envelope which includes some material from the cell membrane; this might resemble the host in antigenic composition to such an extent that any immune response would be relatively weak and slow (Pétursson, 1970). It has also been proposed that the virus itself might cause some modification of the precursors of the cells which play an active role in the immune response of the sheep, which could result in the formation of antibodies with poor combining capacity.

It has recently been found in very protracted experimentally transmitted cases of visna-maedi that if a reisolated virus is compared with the original one, the early sera seem unable to neutralize the reisolated strain to the same titre as the original one. This might indicate an antigenic alteration of the virus in the long presence of the defence mechanism of the host, and might help to explain the progressive illness in spite of the humoral response of the host. This might also explain the variation in maedi strains which can be isolated from a localized outbreak of maedi, which started with introduction of a single virus strain by only one animal (Gudnadóttir, personal communication, 1971). It is also noteworthy that during the epidemic of maedi in Iceland, a certain genetically determined susceptibility was observed (Pálsson, 1943). 


\section{References}

Bunge, R. P., and Harter, D. H. (1969). Cytopathic effects of visna virus in cultured mammalian nervous tissue. J. Neuropath. exp. Neurol., 28, 185-194.

Coward, J. E., Harter, D. H., and Morgan, C. (1970). Electron microscopic observations of visna virus-infected cell cultures. Virology, 40, 1030-1038.

De Boer, G. F. (1970a). Antibody formation in Zwoegerziekte, a slow infection in sheep. J. Immunol., 104, 414-422.

De Boer, G. F. (1970b). Zwoegerziekte, een persisterende virusinfectie bij schapen. T. Diergeneesk., 95, 725-740.

De Kock, G. (1929). Are lesions of jaagsiekte in sheep of nature neoplasm? Un. S. Afr. Dir. vet. Serv., 15th ann. Rep., 611-641.

Georgsson, G., and Pálsson, P. A. (1971). The histopathology of maedi, a slow viral pneumonia of sheep. Vet. Path., 8, 63-80.

Gíslason, G. (1947). Thættir um innflutning búfjársjúkdóma. Iceland Department of Agriculture Publication, pp. 235-257. Reykjavik.

Gudnadóttir, M. Gíslason, G., and Pálsson, P. A. (1968). Studies on natural cases of maedi in search for diagnostic laboratory methods. Res. vet. Sci., 9, 65-67.

Gudnadóttir, M., and Kristinsdóttir, K. (1967). Complement-fixing antibodies in sera of sheep affected with visna and maedi. J. Immunol., 94, 663-667.

Gudnadóttir, M., and Pálsson, P. A. (1965a). Host-virus interaction in visna infected sheep. J. Immunol., 95, 1116-1120.

Gudnadóttir, M., and Pálsson, P. A. (1965b). Successful transmission of visna by intrapulmonary inoculation. J. infect. Dis., 115, 217-225.

Gudnadóttir, M., and Pálsson, P. A. (1967). Transmission of mædi by inoculation of a virus grown in tissue culture from maediaffected lungs. J. infect. Dis., 117, 1-6.

Harter, D. H., and Choppin, D. W. (1967). Cell-fusing activity of visna virus particles. Virology, 31, 279-288.

Harter, D. H., Hsu, K. C., and Rose, H. M. (1967). Immunofluorescence and cytochemical studies of visna virus in cell culture. J. Virol., 1, 1265-1270.

Harter, D. H., Hsu, K. C., and Rose, H. M. (1968). Multiplication of visna in bovine and porcine cell lines. Proc. Soc. exp. Biol. (N.Y.), 129, 295-300.

Harter, D. H., Rosenkranz, H. S., and Rose, H. M. (1969). Nucleic acid content of visna virus. Proc. Soc. exp. Biol. (N.Y.), 131, 927-933.

Hoff-Jørgensen, R. (1971). Slow virus (visna-maedi) in Danish sheep. In Scottish-Scandinavian Conference on Infectious Diseases, Copenhagen, June 1971.

Kennedy, R. C., Eklund, C. M., Lopez, C., and Hadlow, W. H. (1968) Isolation of a virus from the lungs of Montana sheep affected by progressive pneumonia. Virology, 35, 483-484.

Lin, F. H., and Thormar, H. (1970a). Ribonucleic-acid-dependent deoxyribonucleic acid polymerase in visna virus. J. Virol., 6 , 702-704.

Lin, F. H., and Thormar, H. (1970b). On visna virus: purification and nucleic acid content. Virology, 42, 1140-1143.

Lopez, C., Eklund, C. M., and Hadlow, W. J. (1970). Tissue culture of the virus of progressive pneumonia, a slow infectious disease of sheep. (Abstr.). Bact. Proc., 70, 198.

Lucam, F. (1942). La 'bouhite' our 'lymphomatose pulmonaire maligne du mouton". Rec. Méd. vet., 118, 273-285.

Pálsson, H. (1943). Rannsókn á vionámstrotti íslenzks sauôf jár gegn maeoiveiki. Atvinnudeild Háskólans, Rit Landbúnaoardeildar, A-Fl. 1, Reykjavik

Pautrat, G., Tamalet, J. Chippaux-Hippolite, C., and Brahic, M. (1971). Etude de la structure du virus visna en microscopie électeonique. C.R. Acad. Sci. (Paris), 273, 653-655.

Pétursson, G. (1970). Studies on viral antibodies in visna. In Proceedings of the VIth International Congress of Neuropathology, Paris, 1970, pp. 831-832. Masson, Paris.

Rajya, B. S., and Singh, C. M. (1964). The pathology of pneumonia and associated respiratory disease of sheep and goats. I. Occurrence of jagziekte and maedi in sheep and goats in India. Amer. J. vet. Res., 25, 51-67.
Ressang, A. A., Stam, F. C., and de Boer, G. F. (1966). A meningoleucoencephalomyelitis resembling visna in Dutch zwoeger sheep. Path vet. (Basel), 3, 401-411.

Schlom, J., Harter, D. H., Burny, A., and Spiegelman, S. (1971). DNA polymerase activities in virions of visna virus, a causative agent of a 'slow' neurological disease. Proc. nat. Acad. Sci., (Wash.), 68, 182-186.

Sigurdardóttir, B., and Thormar, H. (1964). Isolation of a viral agent from the lungs of sheep affected with maedi. J. infect. Dis., 114, 55-60.

Sigurdsson, B. (1954). Maedi, a slow progressive pneumonia of sheep: an epizoological and pathological study. Brit. vet. J., 110, 255270.

Sigurdsson, B., Grimsson, H., and Pálsson, P. A. (1952). Maedi a chronic progressive infection of sheep's lungs. J. infect. Dis., 90, 233-241.

Sigurdsson, B., Karcher, D., Van Sande, M., and Lowenthal, A.(1961). Electrophoresis of serum and CSF proteins in sheep neurological diseases. Protides biol. Fluids., 8, 110-111.

Sigurdsson, B., Pálsson, P. A., and van Bogaert, L. (1962). Pathology of visna, transmissible demyelinating disease in sheep in Iceland. Acta neuropath., 1, 343-362.

Sigurdsson, B., Pálsson, P. A., and Grímsson, H. (1957). Visna, a demyelinating transmissible disease of sheep. J. Neuropath. exp. Neurol., 16, 389-403.

Sigurdsson, B., Pálsson, P. A., and Tryggvadóttir, A. (1953). Transmission experiments with maedi. $J$. infect. Dis., 93, 166-175.

Sigurdsson, B., Thormar, H., and Pálsson, P. A. (1960). Cultivation of visna virus in tissue culture. Arch. ges. Virusforsch., 10, 368381

Stone, L. B., Scolnick, E., Takemoto, K. K., and Aaronson, S. A. (1971). Visna virus: a slow virus with an RNA dependent DNA polymerase. Nature (Lond.), 229, 257-258.

Straub, O. C. (1970). Über die Isolierung von Maedi-Visna-Virus (MVV) aus einem deutschen Schafbestand. Berl. Münch. tierärzt. Wschr., 83, 357-360.

Takemoto, K. K., Mattern, C. F. T., Stone, L. B., Coe, J. E., and Lavell, G. (1971). Antigenic and morphological similarities of progressive pneumonia virus, a recently isolated 'slow virus' of sheep, to visna and maedi viruses. J. Virol., 7, 301-308.

Thormar, H. (1961). An electron microscope study of tissue cultures infected with visna virus. Virology, 14, 463-475.

Thormar, H. (1965a). A comparison of visna and maedi viruses. 1. Physical, chemical and biological properties. Res. vet. Sci., 6 , 117-129.

Thormar, H. (1965b). Physical, chemical and bilogical properties of visna virus and its relationship to other animal viruses. In Slow, Latent, and Temperate Virus Infections (NINDB Monograph, No. 2), edited by D. C. Gajdusek, C. J. Gibbs, and M. Alpers,pp. 335-340. National Institute of Neurological Diseases and Blindness, Washington, D.C.

Thormar, H. (1966). A study of maedi virus. In Lung Tumours in Animals: Proceedings of the 3rd Quadrennial Conference on Cancer, University of Perugia, 1965, edited by L. Severi, pp. 393-402. A Study of Visna and Maedi Viruses and Their Relationship to Other Viruses of Animals, pp. 1-29. Dansk Videnskabs Forlag, Copenhagen.

Thormar, H. (1969). Visna and maedi virus antigen in infected cell cultures studied by the fluorescent antibody technique. Acta path. microbiol. scand., 75, 296-302.

Thormar, H, and Cruickshank, J. G. (1965). The structure of visna virus studied by the negative staining technique. Virology, 25, 145-148.

Thormar, H., Gíslason, G., and Helgadóttir, H. (1966). A survey of neutralizing antibodies against maedi virus in sera from flocks of sheep affected with maedi and from healthy flocks. J. infect . Dis., 116, 41-47.

Thormar, H., and Helgadóttir, H. (1965). A comparison of visna and maedi viruses. II. Serological relationship. Res. vet. Sct., 6, 456-465.

Wandera, J. G. (1970). Progressive interstitial pneumonia (maedi) of sheep in Kenya. Vet. Rec., 86, 434-438. 